\title{
Determinants of the Stock Price Volatility in the Indonesian Manufacturing Sector
}

\author{
Heny Handayani", Harjum Muharam**, Wisnu Mawardi**, \\ Robiyanto Robiyanto*** \\ * Sekolah Tinggi Ilmu Administrasi Lembaga Administrasi Negara (STIA LAN) Bandung, Jalan Cimandiri No.34-38, Citarum, \\ Bandung Wetan, Kota Bandung, Jawa Barat 40115 \\ ** Faculty of Economics and Business Universitas Diponegoro, Jl. Prof. Soedarto, SH., Tembalang, Semarang 50246 \\ *** Faculty of Economics and Business Universitas Kristen Satya Wacana, Salatiga, Jl. Diponegoro 52-60, Salatiga 50711
}

\begin{tabular}{l} 
A R T I C L E I N F O \\
\hline Keywords: \\
Return on Equity, \\
Debt to Equity Ratio, \\
Sales Growth, \\
Company Size, \\
Cash Ratio, \\
Dividend Payout Ratio, \\
Price Volatility Stocks, \\
Manufacturing Company \\
Kata kunci: \\
Return on Equity (ROE), \\
Debt to Equity Ratio (DER), \\
Pertumbuhan Penjualan, \\
Ukuran Perusahaan, \\
Cash Ratio (CR), \\
Dividend Payout Ratio(DPR), \\
Volatilitas harga saham, \\
Perusahaan manufaktur.
\end{tabular}

Corresponding author:

h.handayani22@gmail.com

\section{A B S T R A C T}

This study aimed to analyze the influence of return on equity, debt to equity ratio, sales growth, firm size, cash ratio, and dividend payout ratio to stock price volatility companies listed on the Indonesia Stock Exchange in the period 2011-2015. The populations of this study are all manufacturing companies listed in Indonesia Stock Exchange (IDX) in the period 2011 to 2015 . It obtained eight companies samples with technique purposive sampling method. The data analysis technique used is the regression model panel then be adjusted again by using GARCH (Generalized Autoregressive Conditional Heteroscedasticity). The results showed that the volatility of the stock price only affect without any effect ARCH-GARCH therein. Determining the best models of each prediction is based on estimated volatility $\operatorname{GARCH}(p, q)$. The determination of whether there is influence of the factors believed to be the determinants of stock price volatility was done by using panel data regression analysis. The results of panel data regression analysis showed that the company's stock price volatility in the research samples can be explained by $4.84 \%$ by ROE, CR, DER, DPR, company size and sales growth while the remaining $95.16 \%$ explained by other variables outside the research. Only sales growth has significant positive effect on stock price volatility.

\section{SARI PATI}

Penelitian ini bertujuan untuk menganalisis pengaruh dari Return on Equity (ROE), Debt to Equity Ratio (DER), pertumbuhan penjualan, ukuran perusahaan, Cash Ratio (CR), dan Dividend Payout Ratio (DPR) terhadap volatilitas harga saham perusahaan-perusahaan yang tercatat di Bursa Efek Indonesia selama periode tahun 2011-2015. Populasi dalam penelitian ini adalah semua perusahaan sektor manufaktur yang tercatat di Bursa Efek Indonesia (BEI) selama periode tahun 20112015. Dengan menggunakan metode purposive sampling diperoleh sampel sebanyak delapan perusahaan. Teknik analisis data yang dipergunakan adalah model regresi panel yang kemudian disesuaikan 
kembali dengan menggunakan GARCH (Generalized Autoregressive Conditional Heteroscedasticity). Hasil penelitian ini menunjukkan bahwa volatilitas harga saham tidak mengandung unsur ARCHGARCH. Hasil analisis regresi panel menunjukkan bahwa ROE, CR, $D E R, D P R$, ukuran perusahaan dan pertumbuhan penjualan mampu menjelaskan 4,84\% variasi dalam volatilitas harga saham, sedangkan 95,16\% variasi dalam volatilitas harga saham dijelaskan oleh variabel lain yang tidak dipergunakan. Hanya pertumbuhan penjualan yang memiliki pengaruh positif yang signifikan terhadap volatilitas harga saham.

(C) 2018 IRJBS, All rights reserved.

\section{INTRODUCTION}

The company's capital needs and the investment activity of investors are key aspects in a capital market. Investors often invest their fund in the stock market into stock purchases. By buying stocks, investors expects return that can be obtained in the form of dividend or capital gain (R. Ernayani \& Robiyanto, 2016; Taliawo \& Atahau, 2007). An investor will find out about the potential of a stock to be purchased. One way that can be used to analyze the potential for profit and loss is by looking at stock price volatility statistics. Volatility can cause risk and uncertainty faced by investors (Robiyanto, Wahyudi, \& Pangestuti, 2017), the higher and the impact on the instability of investor interest in investing the funds. Some investors tend to like stocks that have a high level of volatility because the chances of gaining capital gains will be even greater although on the other side the greater the risk will be obtained.

Hartono (2015) suggests that there are several factors that can affect the company's stock movement (stock volatility). One of them is the dividend payout rate of the company or commonly called dividend payout ratio. The return of dividends paid attention by investors, and the level of their investment risk (stocks) may affect the value of the company's stock in the long run (Dong, Robinson, \& Veld, 2005; R. Ernayani, Oktiviana, \& Robiyanto, 2017; Pujiono, 2002). Furthermore, the higher dividend to be paid, which higher than estimated will cause a signal for investors, that the company's management will expect future earnings to increase. This will generate a positive reaction so that stock prices rise (Lonkani \& Ratchusanti, 2005; Tyastari, Rosidi, \& Saraswati, 2017).

The stock price volatility in addition to being influenced by the dividend payout ratio (DPR) of a company is also influenced by the financial performance of the company itself (Gusni, 2017). Skinner and Soltes (2009); Suharli (2007) argues that companies with good financial performance will be more attractive to investors. Growth of financial performance of the company will be a consideration that has a big effect on investment decisions by investors. Growing financial performance will increase investor interest so that stocks of the company will be more widely traded (Taungke \& Supramono, 2015).

One of the most important and crucial financial performance ratios is profitability ratios (R. Ernayani, Robiyanto, \& Sudjinan, 2017; Mai, 2017). Profitability is an indicator of company performance associated with the ability of companies to gain 
profits, while liquidity is the ratio of corporate financial performance indicators reviewed from the company's ability to pay the debt burden borne by the company in the operational framework of the company itself (Arifin, 2014). Profitability by own equity (return on equity) will be the basis of excellent assessment for investors in assessing how big the prospects of future developments in the company (Jumono, Achsani, Hakim, \& Firdaus, 2016; Utami \& Rahayu, 2004).

Brigham and Houston (2012) argue that the change in stock price after dividend distribution shows that dividends contain important information or reservations in the announcement of the dividends. According to Pujiono (2002), the major influence that will occur by the dividend policy is that the policy will directly affect the company's financial leverage negatively. This can be interpreted that Debt to Equity Ratio (DER) will increase by the proportion of dividends to be distributed. Increasing the value of leverage, then the assessment of the company to be bad, and will further affect the stock price in the market. Referring to this description, it can be concluded that the debt to equity ratio (DER) as an indicator of the company's capital structure will affect the stock price volatility of the company. According to Eviani (2015); Suherman (2017), the capital structure of the company is also shown by the liquidity ratio, i.e., the ratio of the company's ability to meet its short-term liabilities based on the capital owned by the company. The higher liquidity ratio shows the small space of capital owned by the company to perform its operations because most will be used to cover its obligations. This will lower investor interest in buying stocks.

According Hartono (2015), stock price volatility also influenced by the financial performance of the company is also influenced by the characteristics of the company itself (the size of the company and the growth of the company). Setiyono, Tandelilin, Hartono, and Hanafi (2013) argued that the larger the size of a company, the greater the level of investor interest to invest in the company. This will cause the stock price volatility of the company to increase. Unfortunately, various studies in Indonesia, on stock price volatility tend only to conduct time-based studies based on historical stock price data such as Nastiti and Suharsono (2012); Robiyanto et al. (2017). It is rare that research uses firm performance variables as a factor affecting stock price volatility. Based on those phenomenon, so this study aims to analyze the effect of return on equity, debt to equity ratio, sales growth, size, cash ratio and dividend payout ratio to the volatility of stock price of manufacturing companies listed in the Indonesia Stock Exchange in the period 2011-2015. This study uses a panel data method approach which differ from previous research that mostly use time series method. This study is expected to add perspectives about factors affecting the volatility of stock price of the manufacturing companies listed in the Indonesia Stock Exchange.

\section{Literature Review}

\section{Portfolio Theory}

Portfolio theory is based on the assumption that future rates of return on securities can be estimated and then determine risks with variations in distribution (Hartono, 2015; Robiyanto, 2017). With certain assumptions, portfolio theory results in a linear relationship between risk and return. Portfolio theory relates to investors' estimation of risk and return expectations, measured statistically to make their investment portfolio (Robiyanto, 2018). The assumption in this portfolio theory states that an investor always wants to maximize the expected return from the portfolio, then the investor will put his funds in securities that have the expected maximum yield. Related to this, the company with the volatility of stock prices that tend to positive increase will always attract investors to put funds in the company due to the desire to obtain maximum yield and minimal risk.

\section{Signaling Theory}

Signaling theory focuses on the importance of 
information from firms on decisions outside parties (Loeis \& Prijadi, 2015). Information from a company is required by investors and business actors because of the information contained about the various conditions and records that describe the survival of a company at this time, past, and forecast in the future. As an analytical tool to be able to take various investment decisions, completeness, relevance, and accuracy of information is needed. According Hartono (2015); Triyono and Hartono (2000) announcement that has a positive signal is expected to get a positive reaction from the market at the time of announcement issued. The market will always react to the information issued by the company, where the information is interpreted and analyzed and then categorized as a positive signal as well as a negative signal. Both categories will then give effect in the form of changes in the volume of stock trading companies which can then increase or lower the stock price of the company itself.

\section{Stock Price Volatility}

Volatility is a statistical measure for the fluctuations in the price of a security or commodity over a given period (Robiyanto et al., 2017). Market volatility is assumed as a risk because it can be measured using standard deviation assessment methods. The higher returns from the price of a stock will have an impact on the increasing number of uncertainties and hence increase the volatility (Putra, Atahau, \& Robiyanto, 2018; Robiyanto \& Puryandani, 2015). Investors will not take big risks unless there is a chance to get the benefits that are also great, this is commonly referred to as the term high risk, high return (Hartono, 2015). According Ghozali (2011), the calculation of historical volatility of stock can be measured based on the formula of variance calculation, namely:

$$
\sigma^{2}=\frac{\Sigma(r i-E r)^{2}}{N-1}
$$

Note:

$\sigma^{2} \quad=$ Volatility Variance

ri $\quad=$ stock return
$\mathrm{Er} \quad=$ expected return

$\mathrm{n} \quad=$ number of observation

\section{HYPOTHESIS DEVELOPMENT}

The Effect of Return on Equity on the Stock Price Volatility

According Riyanto (2011), return on equity is the ability of equity to finance all the operational activities of the company and then provide benefits for the owners of capital. Return on equity describes the amount of acquisition of the capital invested or the ability of own capital to generate profits for the shareholders of preferred and common stock. Sartono (2001) explains that the return on equity is the level of ability of companies to earn profits that can then be distributed to the owners of capital.

The profitability of a company will affect the investment interest of the company, where the higher the ability of the company in obtaining profit it will affect the increase of interest in purchasing shares of the company itself, and vice versa low profits will lower interest in buying shares (Hermuningsih, 2013; Utami \& Rahayu, 2004). Both conditions indicate a change in the level of interest in the purchase of shares that in the end according to market mechanism will affect the stock price changes itself (Drees \& Eckwert, 2000). Based on the description, the proposed hypothesis is as follows:

$\mathrm{H}_{1}$ : Return on Equity has a positive effect on the stock price volatility

\section{The Effect of Debt to Equity Ratio on the Stock} Price Volatility

Hanafi (2013) defines Debt to Equity Ratio as the ratio between the debt and capital owned by the company. Debt to Equity Ratio often used as a proxy of leverage (Drees \& Eckwert, 2000; Rudangga $\&$ Sudiartha, 2016). The higher level of corporate leverage will affect the increased interest in stock buying (Drees \& Eckwert, 2000). In contrast, low ability to earn profit will lower interest in buying stock. Both conditions indicate a change in the level of interest in the purchase of shares that in 
the end according to market mechanism wil affect the stock price changes itself (Rudangga \& Sudiartha, 2016). Investors expect a debt structure that is not too large on a company. So it can be interpreted that the investors make the capital structure as a basis for consideration in investing in a company (Nuswandari, 2013). This means that leverage which is the ratio of debt structure will influence investor decision, and hence leverage have influence to stock price volatility. Based on the description, the hypothesis is proposed:

$\mathrm{H}_{2}$ : Debt to Equity Ratio has a negative effect on the stock price volatility

\section{The Effect of Sales Growth on the Stock Price Volatility}

The growth of the company has implications for the increased availability of corporate funds, and hence will further increase the company's assets thereby this growth will be able to enlarge the size of the company (Raz \& Amir, 2014; Rudangga \& Sudiartha, 2016). The higher the growth rate of the company's sales will be the greater the cash flow of the company, hence the smaller the capital cost of the company itself (Yusintha \& Suryandari, 2010). This shows an inverse relationship between company growth and corporate leverage. The greater the sales growth, the greater the availability of cash, hence the smaller the ratio of the debt ratio to the company's capital (Margaretha \& Rizki, 2010).

Sales growth will have an impact on the profit growth of the company which will make the company's financial performance to increase. Related to this, Eviani (2015); Murhadi (2011) states that the increase in sales of the company will make investors assess the positive value of the company itself, which will ultimately affect the stock price changes of the company. Wiyani (2005) also points out that trading volume is one of the factors affecting stock price volatility, as trading volume will affect investor interest in buying shares of a company. Based on the description, the hypothesis is proposed:
$\mathrm{H}_{3}$ : Sales growth has a positive effect on the stock price volatility

\section{The Effect of Company Size on the Stock Price} Volatility

Kumar, Rajan, and Zingales (1999); Wang (2000) states that firm size is a scale that can classify companies into large and small companies in various ways, including total assets or total assets, stock market value, average sales rate and the amount of sales. The greater the total assets, sales, and market capitalization, the larger the size of the company (Symeou, 2011). Large companies will typically be better able to keep their business alive than small companies that can be spelled out new, and less able to maintain the viability of their businesses. A large company will better manage its company and will, therefore, be able to produce much better financial performance reports than smaller companies.

A larger company will provide a greater level of income and will, therefore, have an impact on the share value of the company (R. Ernayani \& Robiyanto, 2016). The bigger a company, the higher the value of the shares of the company, the smaller the company will be the lower the value of its shares. Changes in the size of the company that can occur at any time, especially when there is a change in the total value of the assets of the company, will be responded by the owners of capital in the stock market.

The size of a company is a description of the ability of the company (Wijaya, 2017). This is because of the size of this company will be able to know how big total assets owned, total sales that can be achieved, and how much the market value of the company in the eyes of investors. The higher the size of a company, the greater the market value of the company in the eyes of investors, where high market value will make the investor interest to invest in a company will be greater (Rudangga \& Sudiartha, 2016; Rumondor, Mangantar, \& Sumarauw, 2015). This means the 
size of the company determines the interest of investors in investing so it can be said that the size of the company affects the volatility of shares of a company. Based on the description, the hypothesis proposed:

$\mathrm{H}_{4}$ : Company size has a positive effect on the stock price volatility

The Effect of Cash Ratio on the Stock Price Volatility Cash Ratio is a performance measurement method that compares the company's cash amount in the form of current assets that can immediately become money against all current debts that become the burden of the company (Cheng, Lu, \& Schaefer, 1996). R. Ernayani et al. (2017) argues that the cash ratio is the ability of all cash and securities to cover the entire amount of current debt that owned by the company. Since the basis of the calculation is a current asset that is considered highly liquid, then the use of this ratio is best used to measure a company's ability to cover all the short-term expenses it incurred.

A company with good financial ratios will have an impact on the company's ability to settle its shortterm liabilities (Harahap, 2008). This capability will provide a greater level of profit to the company because the company's operations will be much better when the short-term obligations of the company have been met. Nur (2014) explains that investors tend to stay away from corporations with substantial financial risks because their stock returns are not expected to be met. This is because a company with a large financial risk indicates a large debt level (Joni \& Lina, 2010; Rumondor et al., 2015). While the cash held has an amount equal to or even smaller than the total debt owned by the company.

Referring to the description, it can be seen that debt is a risk factor, where the comparison of debt to cash is a reflection of the cash ratio of a company. Therefore, it can be said that the cash ratio is a financial risk factor that affects investment interest from investors resulting in the rise and fall of stock prices of these companies. So it can be said that based on the opinion that has been described the cash ratio of a company influences stock price volatility. Based on the description, the hypothesis is proposed:

$\mathrm{H}_{5}$ : Cash ratio has a positive effect on the stock price volatility

\section{The Effect of Dividend Payout Ratio on the Stock Price Volatility}

The dividend payout ratio shows the percentage of each fund earned distributed to the owner in cash, calculated by dividing the company's cash dividend per share by earning per share (Gill, Biger, \& Tibrewala, 2010). Announcement of cash dividend changes issued by the company has information content that resulted in a change reaction on the stock price of the company (Taungke \& Supramono, 2015). Information on these paid dividends is essentially useful to investors as a basis for assessing the prospects of the company in the future (Suharli, 2007).

According to Tyastari et al. (2017), the dividend policy of a company becomes a matter of great concern to investors. Increasing the dividend policy paid can be a positive signal for investors to provide a good prospect assessment of a company that will affect the interest of investors to buy shares of the company, this will affect the increase in stock price of the company (Gusni, 2017; Taungke $\&$ Supramono, 2015). Based on those description, then the hypothesis proposed:

$\mathrm{H}_{6}$ : Dividend Payout Ratio has a positive effect on the stock price volatility

\section{METHODS}

\section{Data and Technique of Analysis}

The type of data used in this study is in the form of secondary data. Source of data used comes from the financial statements of the period 2011 to 2015. The data in this study is panel data that is the type of data that is a combination of cross-sectional data and time series data, and therefore according to Gujarati (2003), the method of analysis is a 
combination of time series data analysis and crosssectional data analysis. Regression analysis is used to answer research questions, and because the data used is panel data, then the regression model developed is a panel regression model. However, due to the volatility in the dependent variable of the research is stock price volatility, then the regression analysis method of panel is then more adjusted again by using GARCH (Generalized Autoregressive Conditional Heteroscedasticity) method. The form of GARCH analysis in this study is based on the data series of each company. In this research, GARCH analysis for each company is done separately to form the model of volatility of each company. The GARCH analysis consists of several stages including normality test, ARCH effect test, GARCH Model Estimation based on research analysis.

The statistical panel data model used in this study as follows:

Volatility $=\alpha+\beta_{1} \mathrm{ROE}-\beta_{2} \mathrm{DER}+\beta_{3}$ Growth + $\beta_{4} \mathrm{Size}+\beta_{5} \mathrm{CR}+\beta_{6} \mathrm{DPR}+\mathrm{e}$

Where,

Volatility : Stock volatility

$\alpha \quad$ : Constant

$\beta_{1, \ldots,} \beta_{5} \quad$ : Regression coefficient

ROE : Return on Equity

DER : Debt to Equity Ratio

Growth : Sales growth
Size : Company size

DPR : Dividend payout ratio

e : residual error

\section{Sample}

The sample is taken by using purposive sampling method. The criteria of samples are:

1. Manufacturing companies listing BEI period 2011-2015, and not delisted during the research period;

2. Has been listed on the Stock Exchange since December 30, 2010;

3. The Company includes annual reports and audited financial statements by independent auditors;

4. The Company disclose the items needed to be able to assess the dividend per-share, earnings per share, and market price per share.

Based on these criteria, eight companies obtained as samples, namely (according its ticker quotes in the Indonesia Stock Exchange): ALDO, ALMI, ASII, AUTO, BRNA, GGRM, KAEF, and MLIA.

\section{RESULTS AND DISCUSSIONS \\ Data Normality Test Results}

Normality test of the study was conducted based on Jarque-Bera normality test technique by utilizing the normality test facility in the EVIEWS 9.5 program. The results of normality test are shown in Table 1.

Table 1. Data Normality Test Results

\begin{tabular}{|c|c|c|c|}
\hline Ticker Quote & Jarque-Bera & Chi-Square Table Value & Remark \\
\hline ALDO & 1.998235 & \multirow{8}{*}{30.1435} & Normally Distributed \\
\hline ALMI & 5.919159 & & Normally Distributed \\
\hline ASII & 239.5232 & & Not Normally Distributed \\
\hline AUTO & 44.89685 & & Not Normally Distributed \\
\hline BRNA & 10.73562 & & Normally Distributed \\
\hline GGRM & 1.750055 & & Normally Distributed \\
\hline KAEF & 1.998235 & & Normally Distributed \\
\hline MLIA & 5.919159 & & Normally Distributed \\
\hline
\end{tabular}

Source: Secondary data, processed 
Table 1. shows that of the eight volatility models studied there are six models that have normal data distribution and two models with abnormal data distribution. For models with abnormal data distribution, then in testing $\mathrm{ARCH}$ and $\mathrm{GARCH}$ effect tolerance of abnormalities using Generalized Error Deviance method while for volatility model with normal data distribution is done by testing the effect without such method.

\section{Data Stationarity Test Results}

Data stationarity test conducted by using Augmented Dickey-Fuller test statistic. The results of data stationarity test are shown in Table 2. All data used in this study have Augmented Dickey-Fuller test statistics which significant in 5\% significance level. These findings show that no unit roots found.

\section{ARCH-LM Test Results}

The test was performed using the ARCH-LM. The requirement of the presence or absence of $\mathrm{ARCH}$ effect of each volatility model is the magnitude of significant value which should be smaller or equal to 0.05 .

Based on the results as shown in Table 3., it can be seen that from 8 models, it is found that the whole model has no ARCH effect. For models which proven not to have an $\mathrm{ARCH}$ effect then on the GARCH model estimate the order variant proved not involving the $\mathrm{ARCH}$ order, or the $\mathrm{ARCH}$ order is considered 0 so that for the GGRM volatility model, the result of the structural equation does not involve the ARCH coefficients in the model equation.

Table 2. Data Stationarity Test Results

\begin{tabular}{ccc}
\hline Ticker Quote & $\begin{array}{c}\text { Augmented Dickey-Fuller } \\
\text { test statistic }\end{array}$ & Probability \\
\hline ALDO & -3.319140 & 0.0376 \\
ALMI & -3.218150 & 0.0389 \\
ASII & -4.236016 & 0.0043 \\
AUTO & -3.419901 & 0.0251 \\
BRNA & -4.559990 & 0.0022 \\
GGRM & -3.559850 & 0.0123 \\
KAEF & -3.763199 & 0.0155 \\
MLIA & 3.549453 & 0.0179 \\
\hline
\end{tabular}

Source: Secondary data, processed.

Table 3. ARCH- LM Test Results

\begin{tabular}{ccc}
\hline Volatility & Significance & Remarks \\
\hline ALDO & 0.4874 & No ARCH effect \\
ALMI & 0.2085 & No ARCH effect \\
ASII & 0.8868 & No ARCH effect \\
AUTO & 0.6670 & No ARCH effect \\
BRNA & 0.9773 & No ARCH effect \\
GGRM & 0.7987 & No ARCH effect \\
KAEF & 0.6639 & No ARCH effect \\
MLIA & 0.2396 & No ARCH effect \\
\hline
\end{tabular}

Source: Secondary data, processed. 


\section{GARCH Model Estimations}

The GARCH estimation on a volatility model is done by testing the variation of the order $\mathrm{p}$ $(\mathrm{ARCH})$ and the $\mathrm{q}(\mathrm{GARCH})$ order in the observed volatility model. Variations carried out consisted of variations $(1,1) ;(1,2) ;(2,1)$ and $(3,1)$ for models having $\mathrm{ARCH}$ effect and variation $(0,1) ;(0.2)$ and (0.3) for models proven to have no ARCH effect. The ratio of adjusted values of $\mathrm{R}$ Square and also the comparison of significance of each order into consideration in determining the GARCH model of each observed volatility model.

Table 4. GARCH Model Estimation Results

\begin{tabular}{|c|c|c|c|c|c|c|c|}
\hline \multirow{2}{*}{ Model } & \multirow{2}{*}{$\begin{array}{c}\text { Order } \\
\text { Variation }\end{array}$} & \multicolumn{6}{|c|}{ Estimation } \\
\hline & & Adj. R Square & $\mathrm{ARCH}(1)$ & $\mathrm{ARCH}(2)$ & GARCH (1) & GARCH (2) & GARCH (3) \\
\hline \multirow{4}{*}{ ALDO } & $(1,1)$ & -0.087932 & 0.2994 & - & 0.0000 & - & - \\
\hline & $(2,1)$ & -0.133320 & 0.1611 & 0.5164 & 0.6887 & - & - \\
\hline & $(1,2)$ & -0.131577 & 0.2081 & - & 0.0014 & 0.1568 & - \\
\hline & $(1,3)$ & -0.120625 & 0.0042 & - & 0.3787 & 0.8191 & 0.7074 \\
\hline \multirow{4}{*}{ ALMI } & $(1,1)$ & -0.319754 & 0.0105 & - & 0.0139 & - & - \\
\hline & $(2,1)$ & -0.303186 & 0.2196 & 0.4419 & 0.7509 & - & - \\
\hline & $(1,2)$ & -0.308353 & 0.0199 & - & 0.7685 & 0.9104 & - \\
\hline & $(1,3)$ & -0.194721 & 0.4380 & - & 0.7970 & 0.9807 & 0.8259 \\
\hline \multirow{4}{*}{ ASII } & $(1,1)$ & -0.012924 & 0.7644 & - & 0.7222 & - & - \\
\hline & $(2,1)$ & -0.033997 & 0.7668 & 0.5502 & 0.6871 & - & - \\
\hline & $(1,2)$ & -0.011110 & 0.8870 & - & 0.9042 & 0.9934 & - \\
\hline & $(1,3)$ & -0.014243 & 0.7975 & - & 0.7747 & 0.9881 & 0.9839 \\
\hline \multirow{4}{*}{ AUTO } & $(1,1)$ & -0.063812 & 0.0000 & - & 0.0000 & - & - \\
\hline & $(2,1)$ & -0.140430 & 0.0000 & 0.0280 & 0.0480 & - & - \\
\hline & $(1,2)$ & -0.090842 & 0.0012 & - & 0.0861 & 0.3064 & - \\
\hline & $(1,3)$ & -0.098039 & 0.0027 & - & 0.4058 & 0.8536 & 0.8428 \\
\hline \multirow{4}{*}{ BRNA } & $(1,1)$ & -0.000732 & 0.0000 & - & 0.5932 & - & - \\
\hline & $(2,1)$ & -0.076890 & 0.8182 & 0.5470 & 0.7860 & - & - \\
\hline & $(1,2)$ & -0.000712 & $0, .0880$ & - & 0.7959 & 0.9961 & - \\
\hline & $(1,3)$ & -0.002069 & 0.2368 & - & 0.8420 & 0.9987 & 0.9951 \\
\hline \multirow{4}{*}{ GGRM } & $(1,1)$ & $-0,194444$ & 0.0579 & - & 0.0004 & - & - \\
\hline & $(2,1)$ & -0.001427 & 0.6776 & 0.3533 & 0.6791 & - & - \\
\hline & $(1,2)$ & $-0,163614$ & 0.1592 & - & 0.2105 & 0.5887 & - \\
\hline & $(1,3)$ & $-0,167246$ & 0.2406 & - & 0.2610 & 0.6195 & 0.9233 \\
\hline \multirow{4}{*}{ KAEF } & $(1,1)$ & -0.005016 & 0.0735 & - & 0.1705 & - & - \\
\hline & $(2,1)$ & -0.000015 & 0.2104 & 0.0116 & 0.0044 & - & - \\
\hline & $(1,2)$ & -0.007262 & 0.1256 & - & 0.3956 & 0.8874 & - \\
\hline & $(1,3)$ & -0.000931 & 0.0685 & - & 0.4612 & 0.8995 & 0.8775 \\
\hline \multirow{4}{*}{ MLIA } & $(1,1)$ & -0.389372 & 0.0015 & - & 0.0000 & - & - \\
\hline & $(2,1)$ & -0.131414 & 0.9583 & 0.8186 & 0.6950 & - & - \\
\hline & $(1,2)$ & -0.159535 & 0.0080 & - & 0.0871 & 0.6515 & - \\
\hline & $(1,3)$ & -0.083518 & 0.0480 & - & 0.4367 & 0.9205 & 0.9146 \\
\hline
\end{tabular}

Source: Secondary data, processed. 
Based on the estimation of GARCH model, it can be seen that there is a difference of each variation of volatility model which will then be determined the best model for the volatility of each company. The best model to be determined is a model that proves more orders with the smallest significance value and its adjusted $\mathrm{R}$ Square value is largest. The compilation of equation of stock price volatility model based on identification of $\mathrm{ARCH}$ effect proved to be absent, and hence volatility model written does not involve ARCH effect.

\section{Panel Regression Analysis Results}

Regression analysis of panel data in this study was done by first, choosing the most appropriate regression model to be used in the research. There are three regression models that can be proposed, including Ordinary Least Square (OLS)/ Common Effect Model (CEM), Fixed Effects Model (FEM) and Random Effects Model (REM). Test to determine the most appropriate model is done by applying the Hausman test, Chow test, and Lagrange Multiplier test. All three tests are done in sequence with Chow test done first to do Hausman test, or directly to test Lagrange Multiplier.

Based on the above results, it is known that the probability of $\mathrm{F}$ is 0.4381 . This result means probability $\mathrm{F}>0.05$, so it is recommended to use OLS model to estimate the structural equation influence of all independent variables on dependent variable of research. Since the Chow test recommends the use of OLS, the Lagrange Multiplier is then tested to determine whether the OLS or REM model can be used to construct structural equations. Lagrange Multiplier test is done by using calculation technique manually based on comparison between LM value with ChiSquare table value. LM residual test results are as follows:

$$
L M=\frac{n T}{2(T-1)}\left[\frac{T^{2} \sum \hat{e}^{2}}{\sum e^{2}}-1\right]
$$

Whereas:

$\mathrm{n} \quad$ = number of company

$\mathrm{T}=$ number of period

$\sum \hat{\mathrm{e}}=$ sum of average residual square

$\sum \mathrm{e}=$ sum of residual square

The result of calculation value obtained $L M$ value of 9.47368 where the value is smaller than ChiSquare table of 30.1435. Since LM value < ChiSquare table, it was concluded that the model used for the structural equation of research is OLS model. But in order check the robustness of the model, FEM and REM also done. The result of panel regression with OLS (Common Effect Model/), FEM and REM method shown in Table 6.

Based on Table 6., obtains regression equation as follows:

$$
\begin{aligned}
\text { Volatility }= & -0.000751-2.01 \mathrm{E} 05 \mathrm{ROE}+ \\
& 2.73 \mathrm{E}-12 \mathrm{DER}+5.40 \mathrm{E}-06 \mathrm{Growth} \\
& +8.85 \mathrm{E}-05 \mathrm{Size}+2.55 \mathrm{E}-05 \mathrm{CR}- \\
& 1.89 \mathrm{E}-06 \mathrm{DPR}+\mathrm{e}
\end{aligned}
$$

The meaning of the above equation are:

1. Constant of -0.000751 means that the stock volatility in the research sample company is -0.000751 under normal conditions if all independent variables are not changed;

2. The coefficient of ROE effect on volatility is (-) 2.01E05 which means that ROE has negative effect 2.01E05 to volatility. Means if the ROE

Table 5. Chow Test Result

\begin{tabular}{lccc}
\hline \multicolumn{1}{c}{ Effects Test } & Statistic & d.f. & Prob. \\
\hline Cross-section F & 0.993915 & $(7.146)$ & 0.4381 \\
Cross-section Chi-square & 7.448455 & 7 & 0.3837 \\
\hline
\end{tabular}

Source: Secondary data, processed. 
Table 5. Chow Test Result

\begin{tabular}{|c|c|c|c|}
\hline Variable & OLS/CEM & FEM & REM \\
\hline \multirow[t]{3}{*}{ Constant } & -0.000751 & -0.011965 & -0.000751 \\
\hline & $(0.001432)$ & $(0.009513)$ & $(0.001433)$ \\
\hline & [0.524020] & [-1.257837] & {$[-0.523947]$} \\
\hline \multirow[t]{3}{*}{$\mathrm{CR}$} & $2.55 \mathrm{E}-05$ & $-2.47 \mathrm{E}-06$ & 2.55E-05 \\
\hline & (2.03E-05) & (3.28E-05) & (2.03E-05) \\
\hline & [1.257848] & {$[-0.075280]$} & [1.257673] \\
\hline \multirow[t]{3}{*}{ DER } & 2.73E-12 & $-6.62 \mathrm{E}-11$ & 2.73E-12 \\
\hline & (7.06E-10) & (8.11E-10) & $(7.06 \mathrm{E}-10)$ \\
\hline & {$[0.003863]$} & {$[-0.081585]$} & [0.003863] \\
\hline \multirow[t]{3}{*}{ DPR } & -1.89E-06 & $1.47 \mathrm{E}-06$ & -1.89E-06 \\
\hline & $(1.85 \mathrm{E}-06)$ & $(2.78 \mathrm{E}-06)$ & $(1.85 \mathrm{E}-06)$ \\
\hline & [-1.025764] & [0.527733] & {$[-1.025621]$} \\
\hline \multirow[t]{3}{*}{ GROWTH } & $5.40 \mathrm{E}-06^{*}$ & $6.36 \mathrm{E}-06^{* *}$ & $5.40 \mathrm{E}-06^{*}$ \\
\hline & (3.04E-06) & (3.17E-06) & $(3.04 \mathrm{E}-06)$ \\
\hline & [1.775578] & [2.006294] & [1.775331] \\
\hline \multirow[t]{3}{*}{ ROE } & $-2.01 \mathrm{E}-05$ & $-4.96 \mathrm{E}-06$ & $-2.01 \mathrm{E}-05$ \\
\hline & (1.79E-05) & $(2.22 \mathrm{E}-05)$ & $(1.79 \mathrm{E}-05)$ \\
\hline & [-1.123394] & {$[-0.223892]$} & [-1.123238] \\
\hline \multirow[t]{3}{*}{ SIZE } & 8.85E-05 & 0.000823 & 8.85E-05 \\
\hline & (9.67E-05) & $(0.000617)$ & (9.67E-05) \\
\hline & [0.915409] & [1.333264] & [0.915281] \\
\hline R Squared & 0.048350 & 0.091636 & 0.048350 \\
\hline F-Statistic & 1.295561 & 1.132970 & 1.295561 \\
\hline
\end{tabular}

Source: Secondary data, processed.

Note:

Number in parentheses is standard error and number in bracket is t-statistic

* significant at $10 \%$ level of significance

** significant at 5\% level of significance

of the company increases it will decrease the volatility of $2.01 \mathrm{E} 05(0.00201 \%)$ from current volatility conditions;

3. The coefficient of DER influence on volatility is $(+)$ 2.73E-12 which means that DER has positive effect of 0.00000000152 to volatility. Means that if the company DER increases then will increase the volatility of 0.000000000273 $(0.0000000273 \%)$ of the current volatility conditions;

4. The coefficient of Sales Growth effect on volatility is $(+) 5.40 \mathrm{E}-06$ which means that Growth has positive effect 0.00000540 to volatility. Means if the Growth of the company increases then it will increase the volatility of $0.00000540(0.000540 \%)$ from its current volatility condition;

5. The coefficient of effect company size to volatility is $(+)$ 8.85E-05 which means that the size of positive effect of 8.85E-05 against volatility. Means if the size of the company increases it will increase the volatility of $0.0000885(0.00885 \%)$ from current volatility conditions;

6. The coefficient of effect of CR to volatility is $(+)$ 2.55E-05 which mean that CR have positive effect $2.55 \mathrm{E}-05$ to volatility. Means if CR increases then it will increase volatility by $0.0000255(0.00255 \%)$ from current volatility condition; 
7. The coefficient of DPR's influence on volatility is (-) 1.89E-06 which means that the Dividend Payout Ratio negatively affects 1.89E-06 against volatility. Means if the Dividend Payout Ratio increases then will reduce the volatility of $0.00000189(0.000189 \%)$ of current volatility conditions.

Based on the result of the panel regression, it is known that ROE does not have a positive and significant effect to volatility, hence hypothesis 1 that stated Return on Equity has a positive effect on the stock price volatility, rejected. DER does not have a negative and significant effect to volatility. Hence hypothesis 2 that Return on Equity has a negative effect on the stock price volatility rejected. The growth of the firm has a positive and significant effect to volatility, hence hypothesis 3 that stated sales growth has a positive effect on the stock price volatility, accepted. Company size does not have a positive and significant effect to volatility. Hence hypothesis 4 that stated Company size has a positive effect on the stock price volatility, rejected. Cash Ratio does not have a positive and significant effect to volatility, hence hypothesis 5 that stated Cash ratio has a positive effect on the stock price volatility, rejected. Dividend Payout Ratio does not have a positive and significant effect to volatility. Hence hypothesis 6 that stated Dividend Payout Ratio has a positive effect on the stock price volatility rejected.

\section{Discussion}

The results of this study have proved that there is a GARCH effect on the volatility of stock prices of manufacturing companies that become the research sample. The existence of the $\mathrm{GARCH}$ effect proves that the trend of stock price volatility of manufacturing companies contains an autocorrelation where the current stock price volatility condition is correlated with the stock price volatility in the past. The existence of this autocorrelation causes stock price volatility can be predicted by estimating GARCH model. This is consistent with Martikainen, Perttunen, and
Puttonen (1995); Robiyanto and Puryandani (2015); Robiyanto et al. (2017); Saadah (2013). The results prove that the prediction of stock price volatility of manufacturing companies can be measured by using the formula that has been prepared for each volatility in each company.

The results of this study have proved that the regression coefficient of Return on Equity has a positive effect, but the effect is not significant to the volatility of the company's stock price. This result consistent with previous research. According Wang and Ma (2014); Wiyani (2005), stock price volatility is determined by several factors one of which is the trading volume of the company itself.

The results of this study have proved that the regression coefficient of Debt to Equity Ratio (DER) has a positive effect, but its effect is not significant to the volatility of the company's stock price. This result is not consistent with previous research. Referring to the opinion expressed by Harahap (2008); Murhadi (2011) that investors expect the existence of a debt structure that is not too large in a company, so the increase in DER will cause the company's stock price to decline. Therefore the volatility of stock prices should show a negative trend, but the result of this study shows that the increase in DER increases the volatility of stock prices.

The result of this research has proven that growth regression coefficient has positive direction and its effect is significant to volatility of company stock price. An increase in the company's growth will increase the stock price volatility. Sales growth will have an impact on the profit growth of the company which will make the company's financial performance to increase. Related to this, Haryanto (2016); Rudangga and Sudiartha (2016); Rumondor et al. (2015) states that the increase in sales of the company will make investors assess the positive value of the company itself, which will ultimately affect the stock price changes. 
This study proved that the regression coefficient of firm size has a positive direction, but the effect is not significant to stock price volatility. According to Wijaya (2017), the size of a company is a description of the ability of the company. This is because of the size of this company will be able to know how big total assets owned, total sales that can be achieved, and how much the market value of the company in the eyes of investors Haryanto (2016). The higher the size of a company, the greater the market value of the firm in the eyes of investors.

The results of this study proves that the regression coefficient Cash Ratio has a positive direction, but do not have significant effect on stock price volatility. R. Ernayani et al. (2017) explains that investors tend to stay away from corporations with substantial financial risks because their stock returns are not expected to be met. This is because a company with a large financial risk indicates a large debt level. While the cash held has an amount equal to or even smaller than the total debt owned by the company.

The results of this study prove that the regression coefficient Dividend Payout Ratio (DPR) has a positive direction and its influence is not significant to stock price volatility. According to Tyastari et al. (2017), the dividend policy of a company becomes a matter of great concern to investors. Increasing the dividend policy paid can be a positive signal for investors to provide a good prospect assessment of a company that will affect the interest of investors to buy shares of the company (Gusni, 2017). This will affect the increase in stock price of the company (R. Ernayani et al., 2017).

\section{MANAGERIAL IMPLICATIONS}

Investors should consider company's sales growth when invest their fund in the Indonesian manufacturing companies listed in the Indonesia Stock Exchange. The higher sales growth will lead to higher stock volatility. A risk-averse investor should avoid a company with high sales growth because its volatility tend to higher than a company with low sales growth. On the contrary, a risk taker investor can invest in high sales growth because its stock volatility tend to higher which could lead to higher return in the short term.

\section{CONCLUSION}

The stock price volatility of the samples from this study proved to have only GARCH effect without any $\mathrm{ARCH}$ effect in it. While the data volatility of research proved not stationary as evidenced through the test of correlogram and stationarity of data. The existence of the GARCH effect supports the results of previous research that has been done by Comin and Mulani (2009). The prediction of stock price volatility on the eight companies is determined by changes in stock prices of each different company. Hence there are eight predictive formulas for each of the volatility of the company. The best model determination of each stock volatility prediction is based on estimation of GARCH model (p, q).

Determination of the presence or absence of influence of the factors suspected to be a determinant of stock price volatility is done by using panel data regression analysis techniques. Referring to the determination of the best model test, it is determined that the panel data regression model used is Ordinary Least Square (OLS)/ Common Effect model, this is in conclusion on the Chow test and Lagrange Multiplier test. The result of panel data regression analysis shows that the volatility of stock price of the samples can be explained by $4.84 \%$ by ROE, CR, DER, DPR, company size and sales growth while the rest equal to $95.16 \%$ explained by other variables outside the study. Only sales growth has significant positive effect on stock price volatility. Hence, future research can use another variables which do not used in this study such as activity ratio and market-based ratio. 
REFERENCES

Arifin, S. (2014). Pengaruh Profitabilitas, Likuiditas, Growth Potential, dan Kepemilikan Manajerial terhadap Kebijakan Dividen.

Brigham, E. F., \& Houston, J. F. (2012). Fundamentals of financial management: Cengage Learning.

Cheng, C. S. A., Lu, C.-S., \& Schaefer, T. F. (1996). Earnings Permanence and the Incremental Information Content of Cash Flows from Operations. Journal of Accounting Research, 34(1), 173-181.

Comin, D., \& Mulani, S. (2009). A Theory of Growth and Volatility at the Aggregate and Firm Level. Journal of Monetary Economics, 56(8), 1023-1042.

Dong, M., Robinson, C., \& Veld, C. (2005). Why individual investors want dividends. Journal of Corporate Finance, 12(1), 121158.

Drees, B., \& Eckwert, B. (2000). Leverage and the Price Volatility of Equity Shares in Equilibrium. Quarterly Review of Economics and Finance, 40, 155-167.

Ernayani, R., Oktiviana, S., \& Robiyanto, R. (2017). The Effect of Return on Investment, Cash Ratio, and Debt to Total Assets Towards Dividend Payout Ratio (A Study Towards Manufacturing Companies Listed in Indonesia Stock Exchange). Advanced Science Letters, 23(8), 7169-7199. doi: https://doi.org/10.1166/asl.2017.9328

Ernayani, R., \& Robiyanto, R. (2016). The effect of the cash flows, gross profit and company size on Indonesian stock returns (a study on the chemical and basic industry companies during the periods of 2009-2014) International Journal of Applied Business and Economic Research, 14(3).

Ernayani, R., Robiyanto, R., \& Sudjinan, S. (2017). Factors influencing profit distribution management of sharia commercial banks in Indonesia. Journal of Economics, Business \& Accountancy Ventura, 20(2). doi: 10.14414/jebav.v20i2.1055

Eviani, A. D. (2015). Pengaruh Struktur Aktiva, Pertumbuhan Penjualan, Dividen Payout Ratio, Likuiditas dan Profitabilitas Terhadap Struktur Modal. Jurnal Akuntansi dan Sistem Teknologi Informasi 11(2), 194-202.

Ghozali, I. (2011). Aplikasi Analisis Multivariate Dengan Menggunakan Program IBM SPSS 19. Semarang: Badan Penerbit Undip.

Gill, A., Biger, N., \& Tibrewala, R. (2010). Determinants of dividend payout ratios: evidence from United States. The Open Business Journal, 3(1).

Gujarati, D. N. (2003). Basic Econometrics: McGraw-Hill Higher Education.

Gusni, G. (2017). The Determinants of Dividend Policy: A Study of Financial Industry in Indonesia. Jurnal Keuangan dan Perbankan 21(4).

Hanafi, M. M. (2013). Manajemen Keuangan. Yogyakarta, Indonesia: BPFE UGM.

Harahap, S. S. (2008). Analisis Kritis Atas Laporan Keuangan. Jakarta: Raja Grafindo Persada.

Hartono, J. (2015). Teori portofolio dan analisis investasi (10th ed.). Yogyakarta, Indonesia: BPFE.

Haryanto, S. (2016). Determinan Permodalan Bank melalui Profitabilitas, Risiko, Ukuran Perusahaan, Efisiensi dan Struktur Aktiva. Jurnal Ekonomi dan Bisnis, 19.

Hermuningsih. (2013). Pengaruh Profitabilitas, Growth Opportunity, Struktur Modal Terhadap Nilai Perusahaan Pada Perusahaan Publik di Indonesia. Buletin Ekonomi Moneter dan Perbankan.

Joni, \& Lina. (2010). Faktor-Faktor Yang Mempengaruhi Struktur Modal. Jurnal Bisnis dan Akuntansi, 12(2).

Jumono, S., Achsani, N. A., Hakim, D. B., \& Firdaus, M. (2016). The Impacts of ALMA Primary Variables on Profitability: An Empirical Study of Indonesian Banking. International Research Journal of Business Studies, 8(1).

Kumar, K. B., Rajan, R. G., \& Zingales, L. (1999). What determines firm size? Working Paper

Loeis, H. P., \& Prijadi, R. (2015). Ambiguity towards Multiple Historical Performance Information Signals: Evidence from Indonesian Open-Ended Mutual Fund Investors. Indonesian Capital Market Review, 7(2), 92-101. doi: 10.21002/icmr. v7i2.4846

Lonkani, R., \& Ratchusanti, S. (2005). Complete Dividend Signal. Working Paper.

Mai, M. U. (2017). Mediation of CSR and Profitability on the Influences of GCG Mechanism to the Firm Value. Jurnal Keuangan dan Perbankan 21(2), 253-264.

Margaretha, F., \& Rizki, R. A. (2010). Faktor-Faktor Yang Mempengaruhi Struktur Modal Pada Industri Manufaktur di Bursa Efek Indonesia Jurnal Bisnis dan Akuntansi, 12(2), 119-130.

Martikainen, T., Perttunen, J., \& Puttonen, V. (1995). Finnish Turn-of-the-Month Effects: Returns, Volume, and Implied Volatility. Journal of Futures Markets, 15(6), 605-615.

Murhadi, W. R. (2011). Determinan Struktur Modal: Studi di Asia Tenggara. Jurnal Manajemen dan Kewirausahaan, 13(2), 91-98.

Nastiti, K. L. A., \& Suharsono, A. (2012). Analisis Volatilitas Saham Perusahaan Go Public Dengan Metode ARCH-GARCH. Jurnal Sains dan Seni ITS, 1(1), 259-264.

Nur, T. (2014). Searching for Determinants of Pay or Not to Pay Cash Dividend in Indonesia. Indonesian Capital Market Review, 6(1). 
Nuswandari, C. (2013). Determinan Struktur Modal Dalam Perspektif Pecking Order Theory dan Agency Theory. Dinamika Akuntansi Keuangan dan Perbankan, 2(1).

Pujiono. (2002). Dampak Kebijakan Dividen Terhadap Harga Saham Pada Waktu Ex-Dividend Day. Jurnal Riset Akuntansi Indonesia, 5(2).

Putra, M. P. S., Atahau, A. D. R., \& Robiyanto, R. (2018). Cross-asset class portfolio between gold and stocks in Indonesia. Economic Journal of Emerging Markets, 10(1), 69-81. doi: 10.20885/ejem.vol10.iss1.art8

Raz, K. R., \& Amir, M. (2014). A Review of Interaction of Financial Leverage and Investment Opportunities on Dividend Policy. Researcher 4.

Riyanto, B. (2011). Dasar-Dasar Pembelanjaan Perusahaan (4th ed.). Yogyakarta, Indonesia: BPFE UGM.

Robiyanto, R. (2017). Performance evaluation and risk aversion rate for several stock indices in Indonesia Stock Exchange. Jurnal Manajemen dan Kewirausahaan, 19(1), 60-64. doi: 10.9744/jmk.19.1.60-64

Robiyanto, R. (2018). Performance Evaluation of Stock Price Indexes in the Indonesia Stock Exchange. International Research Journal of Business Studies, 10(3), 173-182. doi: https://doi.org/10.21632/irjbs.10.3.173-182

Robiyanto, R., \& Puryandani, S. (2015). The Javanese lunar calendar's effect on Indonesian stock returns. Gadjah Mada International Journal of Business, 17(2), 125-137. doi: 10.22146/gamaijb.6906

Robiyanto, R., Wahyudi, S., \& Pangestuti, I. R. D. (2017). The volatility-variability hypotheses testing and hedging effectiveness of precious metals for the Indonesian and Malaysian capital markets. Gadjah Mada International Journal of Business, 19(2), 167-192. doi: 10.22146/gamaijb.26260

Rudangga, I. G. N. G., \& Sudiartha, G. M. (2016). Pengaruh Ukuran Perusahaan, Leverage dan Profitabilitas Terhadap Nilai Perusahaan.

Rumondor, R., Mangantar, M., \& Sumarauw, S. B. J. (2015). Pengaruh Struktur Modal, Ukuran Perusahaan dan Risiko Perusahaan Terhadap Nilai Perusahaan. Jurnal EMBA, 3(3), 159-169.

Saadah, S. (2013). Response Asymmetry in Spillover Volatility: An Empirical Study in the Indonesia and Singapore Stock Market. Indonesian Capital Market Review, 5(2).

Sartono, A. (2001). Manajemen Keuangan Teori dan Aplikasi. Yogyakarta, Indonesia: BPFE UGM.

Setiyono, Tandelilin, E., Hartono, J., \& Hanafi, M. M. (2013). Detecting the Existence of Herding Behavior in Intraday Data: Evidence from the Indonesia Stock Exchange. Gadjah Mada International Journal of Business, 15(1), 27-44.

Skinner, D. J., \& Soltes, E. (2009). What Do Dividends Tell Us About Earnings Quality. Review of Accounting Studies

Suharli, M. (2007). Influence Profitability and Investment Opportunity Set Against Cash Dividend Policy with Variable Strengthening Liquidity As (Study on Companies Listed on the Jakarta Stock Exchange 2002-2003). Journal of Accounting and Finance, 9(1), 9-17.

Suherman. (2017). Apakah Diversitas Gender Memengaruhi Struktur Modal? Bukti Empiris di Indonesia. Jurnal Keuangan dan Perbankan 21(2), 218-227.

Symeou, P. C. (2011). The firm size - performance relationship: an empirical examination of the role of the firm's growth potential. Working Paper.

Taliawo, N., \& Atahau, A. D. R. (2007). Beta dan Implikasinya terhadap Hasil Diversifikasi Saham Di Bursa Efek Jakarta. Jurnal Bisnis dan Ekonomi, 14(2).

Taungke, N., \& Supramono, S. (2015). Ex-dividend Date dan Perubahan Harga Saham. Jurnal Keuangan dan Perbankan, 19(3).

Triyono, \& Hartono, J. (2000). Hubungan Kandungan Informasi Arus Kas, Komponen Arus Kas dan Laba Akuntansi dengan Harga Saham atau Return Saham. Jurnal Riset Akuntansi Indonesia, 3(1).

Tyastari, T. T. D., Rosidi, R., \& Saraswati, E. (2017). Dividend Policy and Corporate Value (A Meta-Analysis). Jurnal Keuangan dan Perbankan 21(3).

Utami, M., \& Rahayu, M. (2004). Peranan profitabilitas, suku bunga, inflasi dan nilai tukar dalam mempengaruhi pasar modal Indonesia selama krisis ekonomi. Jurnal Manajemen dan Kewirausahaan, 5(2).

Wang, X. (2000). Size Effect, Book-to-Market Effect, and Survival. Journal of Multinational Financial Management, 10, 257-273.

Wang, Y., \& Ma, J. (2014). Excess Volatility and the Cross-section of Stock Returns. The North American Journal of Economics and Finance, 27, 1-16. doi: 10.1016/j.najef.2013.10.003

Wijaya, R. (2017). Kinerja Keuangan dan Ukuran Perusahaan terhadap Harga Saham dengan Kebijakan Dividen sebagai Variabel Intervening. Jurnal Keuangan dan Perbankan 21(3).

Wiyani, W. (2005). Pengaruh nilai tukar Rupiah, tingkat suku bunga deposito dan volume perdagangan saham terhadap harga saham. Jurnal Keuangan dan Perbankan, 9(3).

Yusintha, P., \& Suryandari, E. (2010). Analisis Faktor-Faktor Yang Mempengaruhi Struktur Modal (Studi Empiris Pada Perusahaan Manufaktur di Bursa Efek Indonesia). Jurnal Akuntansi dan Investasi, 11(2), 179-188. 